\title{
Movement patterns and habitat selection of the Endangered eastern freshwater cod Maccullochella ikei in the Mann River, Australia
}

\author{
Gavin L. Butler ${ }^{1,2, *}$, Stuart J. Rowland ${ }^{1}$, Peter R. Baverstock ${ }^{2}$, Lyndon Brooks ${ }^{2}$ \\ ${ }^{1}$ Department of Primary Industries NSW, Grafton Fisheries Centre, PMB 2, Grafton, NSW 2460, Australia \\ ${ }^{2}$ Southern Cross University, Graduate Research College, PO Box 157, Lismore, NSW 2480, Australia
}

\begin{abstract}
Movement and migration are fundamental activities in the life history of fishes. It is therefore critical in species conservation that there is a clear understanding of why movements or changes in habitat occur. The aim of the present study was to quantify the movement patterns and habitat selection of the Endangered eastern freshwater cod Maccullochella ikei in relation to river discharge, water temperature and season. Twenty-five adult $M$. ikei were implanted with radio tags and tracked for 12 mo in the Mann River, Australia. Fish were located manually once a week, whilst larger inter-pool movements were monitored continuously by automated tracking stations. Ten $24 \mathrm{~h}$ continuous tracking events were undertaken to quantify diel movement patterns. Underwater cameras were used to verify fixes and observe behaviour. Based on weekly fixes and tracking station data, 2 main types of behaviour were observed: extended periods of restricted movement and strong home-site fidelity, and short periods of relative high mobility and home-site shifts. Larger intra- and inter-pool movements were most often related to rises in river discharge. There was also increased movement and home-site shifts by males but not females during the breeding season. Diel behaviour was typified by sedentariness during the day and increased crepuscular and nocturnal activity. Habitat selection was for deep pools, and large boulders and woody debris were preferred as cover. These results suggest that the maintenance and restoration of quality habitat and natural flow regimes are essential for the ongoing conservation of remnant populations of $M$. ikei and for the successful reestablishment of the species in areas where it has become extirpated.
\end{abstract}

KEY WORDS: Maccullochella $\cdot$ Telemetry $\cdot$ River discharge $\cdot$ Reproduction $\cdot$ Threatened species

\section{INTRODUCTION}

The entrainment of waterways and ecologically unsustainable land-use practices have permanently disrupted the movement patterns of many aquatic and terrestrial animal species (Jefferies et al. 2004, Thirgood et al. 2004, Quinn 2005). The effect of these activities has been a marked decline in the abundance of many species, particularly those that have extensive home ranges and those that migrate as part of their natural life history. As has been the case in many river systems throughout the world, the damming and regulation of Australia's streams and rivers has affected the movement and migration patterns of native fish species (Cadwallader 1978, Walker 1985, Arthington \& Pusey 2003). River regulation - in combination with, among other issues, the loss of habitat, overfishing and the introduction of non-native fish species - has brought about a dramatic decline in the abundance of many of the conti- 
nent's freshwater fish species. It is estimated that around 27 of Australia's 300-odd freshwater fish species are now considered threatened with extinction (Froese \& Pauly 2013).

The movement behaviour and habitat use of freshwater fish has been the focus of extensive research throughout the world, including Australia, mainly because of the many issues now surrounding river systems and naturally impounded waters. Such research has included investigations of species that migrate over many thousands of kilometres, through to species in streams and impoundments, where individuals may move only a few hundred metres throughout the entire study (McFarlane et al. 1990). Fish move for a variety of reasons that can include: obligatory migrations to spawning grounds (e.g. Kynard 2003, Quinn \& Myers 2004, Whitfield et al. 2012); voluntary movement when undertaking ontogenetic niche shifts (e.g. Kynard et al. 2003, Rosenberger \& Angermeier 2003); or resource limitations or disturbance compelling an individual to shift to alternative habitats (e.g. Greenberg 1991, Harvey et al. 1999, Crook 2004, Leigh \& Zampatti 2013). However, while the reasons may be many, understanding when and why an individual species moves or changes habitat is an essential component of ensuring its long-term conservation.

The eastern freshwater cod Maccullochella ikei Rowland 1985 is an Endangered species endemic to the Richmond and Clarence River systems of northern New South Wales (Rowland 1993, Harris \& Rowland 1996). One of the largest freshwater fish species in Australia, M. ikei can attain lengths in excess of $1 \mathrm{~m}$ and weights over $40 \mathrm{~kg}$ (Rowland 1993, Butler \& Rowland 2008). A number of natural and anthropogenic-induced environmental events during the 20th century, which included combinations of droughts, bushfires, flooding and releases of mining waste, resulted in a significant reduction in the abundance and range of $M$. ikei. By the late 1970s the species was considered extirpated in the Richmond River system, and only small extant populations remained in isolated sub-catchments of the Clarence River system (Rowland 1993, Butler \& Rowland 2008, 2009). M. ikei is protected under State (Fisheries Management Act 1994) and Commonwealth (Environment Protection and Biodiversity Conservation Act 1999) threatened species legislation, and a range of conservation actions have been implemented to assist in the long-term conservation of the species (New South Wales Fisheries 2004). These actions include a total year-round ban on the take or targeting of $M$. ikei throughout its original range, restock- ing programs (Rowland 2013), as well as a complete fishing closure from August to October to protect breeding individuals across the area encompassing the species' main remnant population (Butler \& Rowland 2009).

There is little information available relating to the movement patterns and habitat use of Maccullochella ikei (Butler 2009). A study by Butler (2001) used radio tags to monitor the diel movements of 6 adult $M$. ikei over 2 mo within the lower sections of the Mann River. No inter-pool movements were recorded, and comparisons of movements in relation to river discharge and water temperature were not attempted. Unlike $M$. ikei, the other Australian freshwater cod species ( $M$. peelii, M. macquariensis and $M$. mariensis) have all been the subject of a number of studies in regards to their movement and habitat selection. In general, all 3 species exhibited similar behaviours. Movement patterns were most often characterised by long periods of relatively high home-site fidelity interspersed with rapid and, in some cases, long-distance movements (Simpson \& Mapleston 2002, Ebner \& Thiem 2009, Koehn et al. 2009, Leigh \& Zampati 2013). There were also generally strong associations with instream structure such as woody debris for all 3 species (Simpson \& Mapleston 2002, Ebner \& Thiem 2009, Koehn 2009).

River discharge is one of the key parameters that dictate the ability of fish to efficiently disperse in lotic environments (Taylor \& Cooke 2012, Radinger \& Wolter 2013). Whilst this applies particularly to migratory species, potadromous fishes such as Australia's freshwater cod species have also been shown to use increases in river discharge to disperse (Simpson \& Mapleston 2002, Koehn et al. 2008, Leigh \& Zampatti 2013). A recent review of the current environmental flow regulations for Maccullochella ikei as part of the Water Sharing Plan process in New South Wales (NSW Water Management Act 2000) highlighted the poor understanding of the species-specific flow requirements (Butler 2009). Additionally, the long-running proposal to dam and divert the waters of the Clarence River and its tributaries (e.g. Page 1944, Rankin and Hill Pty Ltd 1981, Snowy Mountains Engineering Corporation 2007) also has the potential to threaten the long-term conservation of $M$. ikei if the species is shown to undertake obligatory migrations or is reliant on flow to disperse.

The aim of the present study was to quantify the movement patterns and habitat selection of Maccullochella ikei in relation to river discharge, water temperature and season. 


\section{MATERIALS AND METHODS}

\section{Study area}

The Mann River is located on the north coast of New South Wales, Australia, and combined with the Nymboida River makes up the largest sub-catchment of the Clarence River system. The Mann River is considered relatively pristine and is largely unregulated, with only light agriculture carried out throughout most parts of the catchment and only small numbers of low-level weirs, dams and road crossings affecting fish passage across its headwaters (Ferguson et al. 1999a). The Mann River rises along the top of the Great Dividing Range and in comparison to many Australian rivers is relatively short and steep, falling around $1500 \mathrm{~m}$ over a distance of about $200 \mathrm{~km}$.

The lower Mann River catchment is classified as confined river valleys with bedrock-controlled discontinuous floodplains (Ferguson et al. 1999a). The channel morphology of the lower Mann is typified by slow-flowing pool-runs up to $2 \mathrm{~km}$ in length and $100 \mathrm{~m}$ wide, separated by equally long stretches of shallow rapid-riffle zones. Depth in pools can range up to $11 \mathrm{~m}$, with a mean of $\sim 3 \mathrm{~m}$ (Butler 2001). Discharge can be highly variable in a typical year, with seasonal rains often resulting in rapid rises in stream heights of up to $12 \mathrm{~m}$ over periods of less than a week. Generally, the highest discharge events occur in autumn and early winter, with spring storms also producing moderate rises of 1 to $3 \mathrm{~m}$.

The focal area of the present study was approximately $30 \mathrm{~km}$ above the confluence of the Mann and Clarence Rivers $\left(29^{\circ} 32^{\prime} \mathrm{S}, 152^{\circ} 29^{\prime} \mathrm{E}\right)$ and included 3 consecutive pools ranging from 1.2 to $2 \mathrm{~km}$ in length (see Butler \& Rowland 2009). Sequences of rapidriffle-run habitats (see Armantrout 1998 for description) of varying length (100 to $500 \mathrm{~m}$ ) and flow velocity separated the 3 pools. Instream substrate was primarily bedrock, boulders, cobbles and gravel, with smaller areas of sand, mud and silt also present. Bedrock shelves, boulders and small amounts of woody debris provided the majority of instream cover, with relatively large macrophyte beds also present within all 3 pools. Riparian vegetation was relatively sparse, and contained a mix of both native and exotic plants.

\section{Capture and tagging}

Twenty-five Maccullochella ikei were captured for tagging in late 2004 using boat electro-fishing and angling. Eight individuals were taken from each of the 3 pools within the study area, with one taken from a small pool between the 2 upstream pools. All fish had a passive integrated transponder (PIT) tag inserted in the dorsal muscle following capture and were transported the same day to Grafton Fisheries Centre $\left(29^{\circ} 37^{\prime} \mathrm{S}, 152^{\circ} 57^{\prime} \mathrm{E}\right)$. Fish were housed in individual, aerated and partially covered 10001 tanks, with salt $(\mathrm{NaCl})$ added to the water and maintained at 2.5 to $3 \mathrm{~g} \mathrm{l}^{-1}$ to reduce stress, prevent infection by pathogens and promote healing (Selosse \& Rowland 1990).

Fish were implanted with single-stage pulsing radio tags (Model LT1 trailing whip antenna, $151 \mathrm{MHz}$, Titley Electronics) 10 to $14 \mathrm{~d}$ post-capture. Tags weighed on average $( \pm \mathrm{SE}) 20.7 \pm 0.19 \mathrm{~g}$ in air and had a predicted transmitting life of 365 to $420 \mathrm{~d}$. Tag implantation procedures and post-operative care followed those suggested by Butler et al. (2009). Fish were sexed during the implantation procedure using methods described by Rowland (1983). Fish were on average $560 \pm 60.8 \mathrm{~mm}$ in total length (TL) (range = $462-790 \mathrm{~mm}$ ) and $2613 \pm 1110.3 \mathrm{~g}$ in weight (range $=$ $1133-6987 \mathrm{~g})$ for females $(\mathrm{n}=5)$, and $535 \pm 18.1 \mathrm{~mm}$ TL (range $=441-688 \mathrm{~mm}$ ) and $1044 \pm 233.5 \mathrm{~g}$ (range $=968-4156 \mathrm{~g})$ for males $(\mathrm{n}=20)$.

\section{Fish location techniques}

All fish were released on the same day in midMarch 2005. No tracking was undertaken over the first $10 \mathrm{~d}$ after release; 24 of the 25 fish were located on Day 11 (Day 1 is 1 d post-release). Fish were subsequently located once weekly by boat or from the bank ( \pm 1 to $2 \mathrm{~m}$ ) using a hand-held Yagi antenna and an Australis 26K Scanning Receiver (Titley Electronics). A Garmin GPS unit set to AMG WGS 1984 Datum was used to record the position at each fix $( \pm 6.0 \mathrm{~m})$. Mobile underwater cameras (Sunkwang Electronics) were also used throughout the study to validate the positioning of fish and to observe breeding behaviour (see Butler \& Rowland 2009 for detailed methodology). A number of meso- and micro-habitat parameters were recorded at each fish's weekly location to determine habitat selection, including cover type and stream channel type. Water temperature was recorded every $4 \mathrm{~h}$ using a Gemini Tinytalk TK-0014 data logger (Hastings Data-Loggers), positioned in the middle of the 3 pools in $\sim 2.5 \mathrm{~m}$ of water.

Four fixed listening stations were placed at the junctions and ends of the 3 pools to monitor inter- 
pool movements. Stations contained 2 independently tuned Australis 26K scanning receivers attached to a data logger. Each logger continuously scanned across all tag frequencies on a 3-s holdand-scan cycle, with arrival and departure times recorded when a tagged fish passed. Signals were received by two 3-element fixed Yagi antennas (Model AY-3), positioned approximately $5 \mathrm{~m}$ from the ground and directed upstream and downstream of the tower. Based on dummy tag trials, the detection range of stations ranged from 200 to $400 \mathrm{~m}$ of river length.

To determine the diel movement patterns of Maccullochella ikei, continuous tracking events were undertaken within a single diel period in each month from April to December (total = 10). Individuals were located every $2 \mathrm{~h}$ within each period, starting and ending at 17:00 $\mathrm{h}$ on successive days. All tracking was carried out primarily in the uppermost of the 3 pools, but also in adjacent pools if tagged fish moved out of the focal pool during the sampling period. Only male fish were tracked during diel sampling, due to the absence of females in the focal pool. The number of individuals tracked within each sample was as follows: 7 in the first 3 events, 6 in the following 6 events and 4 in the final event. Water depth was also recorded at each fix.

\section{Habitat availability}

The line-transect method as described by Simonson et al. (1994) was used to provide an estimate of the proportion of each cover type available within the study area. Stations were established at 2 pool-run sections $(>2 \mathrm{~km})$ within the area occupied by tagged fish during the study. Transects were $90^{\circ}$ to stream flow, and were spaced within each station at distances of 2 times the mean river width. The first and last transects were at a distance of one-half the mean width of the pool-run from the station's start and end. All cover types directly below the transect line were measured to the nearest $50 \mathrm{~cm}$. The start and end of each cover type was estimated visually from the surface or by an underwater camera where water depth exceeded $3 \mathrm{~m}$. Cover types were: open water, bedrock (shelves), large boulder (>500 mm), small boulder (200 to $500 \mathrm{~mm}$ ), macrophytes and woody debris (Armantrout 1998). Depth was also recorded across each transect at intervals of $5 \mathrm{~m}$.

A survey was undertaken of the total stream length occupied by all tagged fish ( $\mathrm{n}=22.45 \mathrm{~km}$ ) to estimate the proportion of each stream channel type available. Channel types were: pool, glide, run, riffle, rapid, cascade and waterfall (see Armantrout 1998 for definitions). The survey involved following the main thalweg of the river and recording the location of significant changes in the channel morphology across the stream width as a whole. The start and end of each channel type was estimated visually, and the position was recorded using a Garmin 72 GPS unit.

\section{Statistical analyses}

Multilevel (among fish, within individual fish) multinomial (movement: up, down, none) logistic regression (MLR) modelling (MLwiN 2.02; Rasbash et al. 2005) was used to compare the weekly movement patterns of Maccullochella ikei in relation to river discharge, water temperature, season, sex and TL. 'Movements' were considered only as those relocations greater than $100 \mathrm{~m}$, primarily to establish which parameters determined larger intra- and interpool home-site shifts. The distance moved was considered as the shortest length of stream between successive locations. River discharge was considered as the peak discharge (height in $\mathrm{m}$ ) for each week, which was subsequently assigned to 1 of 4 categories: below the 70 th percentile $(<0.656 \mathrm{~m})$, between the 70th and 50th percentiles $(0.656-0.821 \mathrm{~m})$, between the 50th and 30th percentiles (0.821$1.243 \mathrm{~m}$ ) and above the 30th percentile $(>1.243 \mathrm{~m})$. Water temperature was taken as the mean for the week, and seasons were classified as spring, summer, autumn and winter. The Wald statistic was calculated for each combination of factors and significance was tested using a $Z$ normal distribution (Rasbash et al. 2005). Wald statistics $\geq 1.96$ were considered to be significant (2-tailed, p < 0.05). Least squares regression analysis was used to determine whether there was any relationship between the TL of individual fish (ln) and the total stream length (ln) it occupied across the entirety of the study.

Binomial (move, no-move) logistic regression (BLR) modelling (MLwiN 2.02; Rasbash et al. 2005) was used to compare the diel movement patterns of Maccullochella ikei in relation to season and TL. Additionally, multilevel linear models (MLM) were used to establish relationships between diel activity and both distances moved and water depths selected. For the analysis, night was considered as 17:00-04:59 h and day as 05:00-16:59 h. To allow for GPS and location errors, only those relocations greater than $10 \mathrm{~m}$ were considered as a movement. Following initial 
analysis, only movement in spring was found to be significantly different among seasons, allowing summer, winter and autumn data to be combined into 1 group.

Estimates of total available cover were calculated by summing the occurrence of each cover type across all transects combined and expressing the result as a percentage of the total length of all transects. Total available channel types were calculated as a percentage proportion of the total stream length surveyed. Cascades, waterfalls and rapids were combined for the analysis because of their relative low occurrence. Selection ratio analysis (FishTel 1.4; Rogers \& White 2007) was used to determine cover, channel type and depth choice. Bonferroni confidence intervals on the selection ratios were calculated to ensure all intervals contained their true values (Rogers \& White 2007). Selection of a habitat type was considered significant if the ratio was greater than 1 , or if the confidence interval on the ratio did not contain the value 1. Conversely, avoidance was demonstrated when ratios were less than 1 (Rogers \& White 2007). Kruskal-Wallis $H$-tests were used to determine the significance of differences between the weekly depths used by individual Maccullochella ikei. Linear regression analysis was used to determine the relationship between the TL of individual fish (ln) and the mean water depth (ln) in which they were located.

\section{RESULTS}

\section{Initial post-release movements}

Dispersal and settlement of tagged Maccullochella ikei post-release was primarily within release pools, with individuals moving both upstream and downstream from their release points. Only one fish moved out of its release pool during the first $11 \mathrm{~d}$, moving upstream through a series of riffles, rapids and pools before establishing a home site in a large and relatively deep pool. On average, tagged $M$. ikei moved $507 \pm 144 \mathrm{~m}$ (mean $\pm \mathrm{SE}$ ) from their respective release sites over the $11 \mathrm{~d}$ post-release (range = 5-2583 m). Only 1 ind. returned to its original capture site, while 8 others were located within $100 \mathrm{~m}$ of their original capture sites, a further 9 within $200 \mathrm{~m}$ and the remaining 6 ranging from 250 to $2521 \mathrm{~m}$.

During the 3 mo period following release, signals from 7 of the tagged fish were lost. Missing fish were not recorded moving past any of the listening stations, and losses were attributed to either transmitter failure or illegal retention by fishers. These fish were subsequently excluded from any analyses. The remaining 18 (15 male, 3 female) individuals were monitored up until Week 40. Signals from a further 7 individuals were then lost over the following $6 \mathrm{wk}$; the remaining 11 (9 male, 2 female) fish were tracked until Week 52 (Fig. 1).

\section{Weekly movement patterns}

Maccullochella ikei moved both upstream and downstream throughout the study, and within pools as well as among pools. Mean weekly movements of tagged fish varied considerably for both males (range = 36-1549 m) and females (range = 3-2417 m; Fig. 1). Movement patterns were typified by extended periods of relatively sedentary behaviour and high homesite fidelity, followed by rapid, often large-scale, relocations. Waterfalls and riffle-rapid sections of the river often halted relocations, and individuals in many cases remained immediately downstream of these barriers for extended periods until rises in river height allowed passage. Larger longitudinal relocations tended to occur during periods of abovemedian discharge but in most cases after discharge had peaked (Fig. 1). Movement before and during large discharge events was mostly restricted to lateral relocations, often to flooded riparian vegetation. Considerable among-individual differences were recorded in the total stream length occupied, ranging from 11 to $34500 \mathrm{~m}$ (mean $=6938 \pm 2627 \mathrm{~m})$ for males and 500 to $5700 \mathrm{~m}$ (mean = 2313 $\pm 1694 \mathrm{~m}$ ) for females. There was no significant relationship between the size (TL) of individual fish and the total length of stream it occupied $\left(R^{2}=0.1443\right)$.

Data collected from the fixed stations showed that inter-pool movements occurred mainly at night (17:00 to 05:00 h). Fish were also often recorded moving to the top or bottom of pools during the night without moving into adjoining pools. In the few instances where inter-pool movement was recorded in daylight hours, it was generally in association with high-discharge events. Discharge varied considerably throughout the year, with the most significant rise occurring in June (Fig. 1). There were also smaller increases in discharge throughout spring and summer, driven primarily by localised storm events. The lowest discharges were recorded in the months immediately before and after the large flood event in June. Daily river discharge ranged from 0.51 to $3.29 \mathrm{~m}$ height and 187 to $61679 \mathrm{Ml}$ flow, with means of $0.85 \pm 0.019 \mathrm{~m}$ and $2006 \pm 261 \mathrm{Ml}$, respectively. 

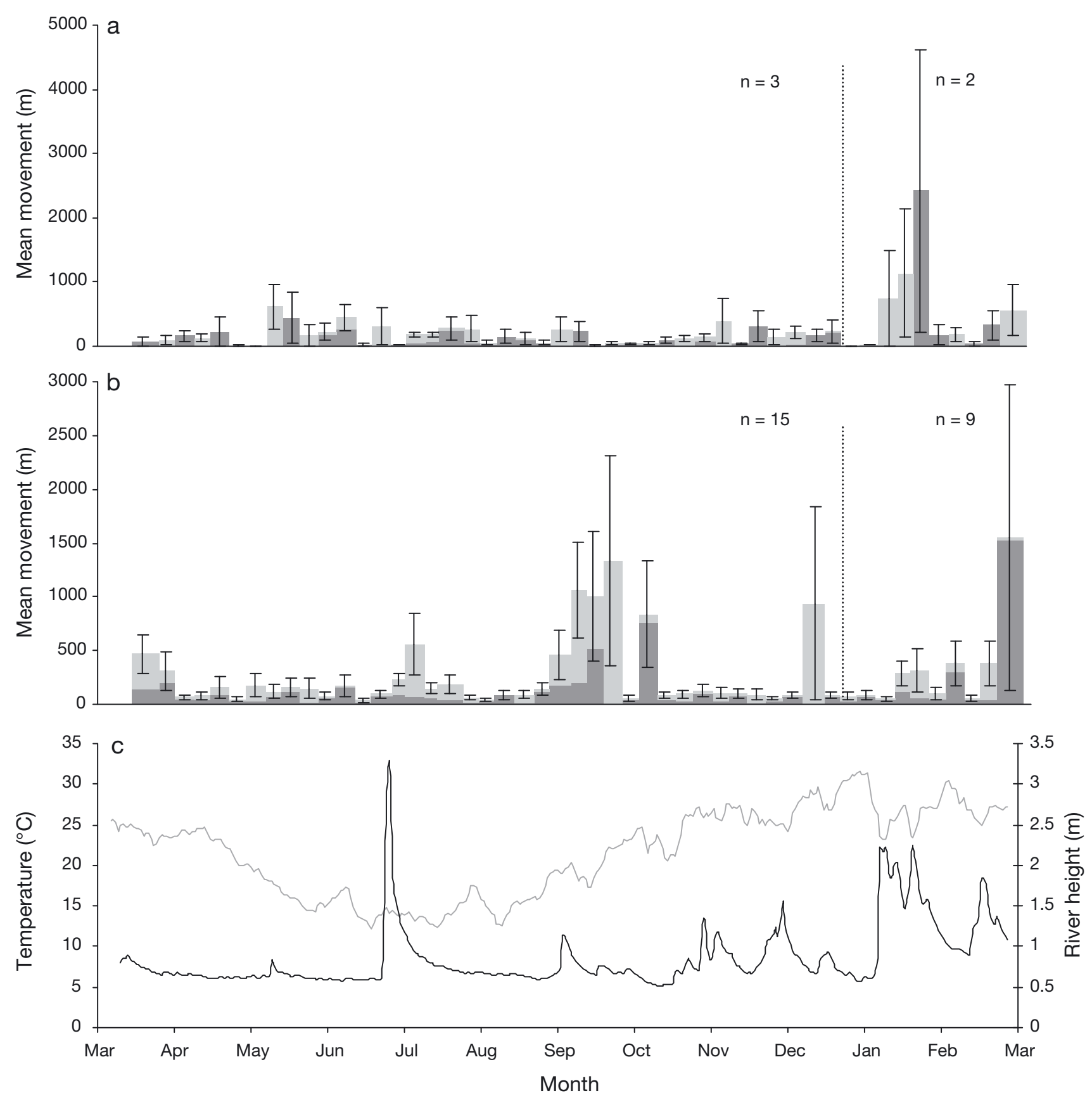

Fig. 1. Maccullochella ikei. Mean ( \pm SE) weekly movement (upstream: light grey bars; downstream: dark grey bars) of (a) female and (b) male Mikei in the Mann River, Australia; (c) shows temperature (grey line) and river height (black line) data. Vertical dotted lines indicate change in the number of tagged Maccullochella ikei over time

The larger intra- and inter-pool weekly movements by Maccullochella ikei (>100 m) were primarily related to increases in river discharge (Table 1). This was particularly the case with upstream movements, as there was significantly more movement when discharge was above the 50th percentile compared with when it was below the 70th percentile (MLR, $\mathrm{p}<0.01$ ). Downstream movements were also influ- enced by discharge, with flows $>30$ th percentile resulting in significantly increased activity (MLR, $p=0.02$ ). There was significantly more movement upstream in winter and spring than in summer (Table 1). The greatest cumulative increase in distance moved by males also occurred during winter and spring in comparison to other seasons (Fig. 1). There was no significant difference in downstream 
Table 1. Partial coefficients and probability values for multinomial logistic regression analysis of weekly movement patterns of Maccullochella ikei. The reference categories for discharge and season are: below the 70th percentile and summer, respectively

\begin{tabular}{|c|c|c|c|c|}
\hline \multirow[t]{2}{*}{ Variable } & \multicolumn{2}{|c|}{ No vs. upstream movement } & \multicolumn{2}{|c|}{ No vs. downstream movement } \\
\hline & Coefficient $( \pm \mathrm{SE})$ & $\mathrm{p}$ & Coefficient $( \pm \mathrm{SE})$ & $\mathrm{p}$ \\
\hline \multicolumn{5}{|l|}{ Discharge } \\
\hline Between 70th \& 50th percentiles & $0.245(0.302)$ & 0.42 & $-0.218(0.275)$ & 0.40 \\
\hline Between 50th \& 30th percentiles & $1.072(0.365)$ & $<0.01$ & $0.329(0.358)$ & 0.36 \\
\hline Above 30th percentile & $0.995(0.351)$ & $<0.01$ & $0.770(0.320)$ & 0.02 \\
\hline Mean weekly temperature & $-0.105(0.041)$ & 0.01 & $-0.003(0.044)$ & 0.97 \\
\hline \multicolumn{5}{|l|}{ Season } \\
\hline Spring & $-0.758(0.356)$ & 0.03 & $0.316(0.362)$ & 0.38 \\
\hline Autumn & $-0.722(0.457)$ & 0.11 & $0.029(0.456)$ & 0.95 \\
\hline Winter & $-1.200(0.611)$ & 0.05 & $0.398(0.642)$ & 0.54 \\
\hline
\end{tabular}

movement in any season. Likewise, there was no significant relationship $(\mathrm{p}>0.05)$ between movement and size (TL) or sex.

Water temperature varied considerably throughout the study. The lowest temperature was recorded in the first month of winter $\left(\right.$ June $\left.=12.2^{\circ} \mathrm{C}\right)$ and the highest in mid-summer (January $=31.6^{\circ} \mathrm{C}$; Fig. 1). Changes in water temperature, while primarily related to seasonal variations, were also influenced by changes in river discharge. River rises in most cases resulted in a corresponding decline in temperature by up to $7^{\circ} \mathrm{C}$ (Fig. 1). Water temperature also influenced the movement of Maccullochella ikei, as there was a negative relationship between rising water temperature and upstream movement (MLR, $p=0.01$; Table 1 ). There was no significant relationship between water temperature and downstream movement (MLR, $\mathrm{p}=0.97$ ).

\section{Spawning season movements}

Based on visual observations by underwater camera, 7 of the 15 tagged male Maccullochella ikei spawned during September, and a further 4 males established nesting sites but did not spawn. All males that successfully spawned had relocated from their previous week's position, moving both upstream and downstream and within pools as well as among pools. All sites used for breeding had not been used by any of the tagged males previously during the study. Distance moved from the previous week's fix ranged from 31 to
$3920 \mathrm{~m}$ (mean $=945 \pm 527.7 \mathrm{~m})$, and the longest movements were upstream. Nesting lasted between 4 and $5 \mathrm{wk}$, and there was little or no apparent movement during this period. Nest sites were subsequently abandoned at the completion of the breeding cycle. Only one fish subsequently returned to its breeding site during the remainder of the study. Over a 2-wk period following the abandonment of nesting sites, all individuals returned to the general area they occupied prior to breeding. No significant increase in activity by females was observed during this period.

\section{Diel movement patterns}

There were significantly more movements $>10 \mathrm{~m}$ during the night than during the day (BLR, $\mathrm{p}=0.02$; Fig. 2). The longest mean movements occurred between 05:00 and 07:00 $\mathrm{h}($ mean $=90 \pm 16.3 \mathrm{~m})$ and 17:00 and 19:00 $\mathrm{h}($ mean $=88 \pm 18.7 \mathrm{~m})$, while the

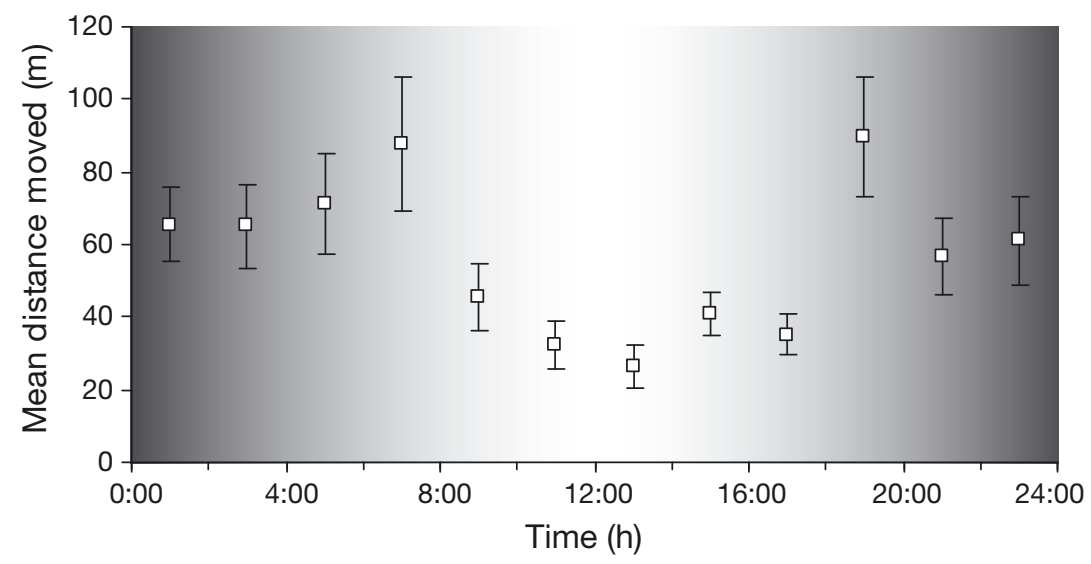

Fig. 2. Maccullochella ikei. Distance moved by fish during diel sampling (night: grey; day: white). Data are means $\pm \mathrm{SE}$ 
least amount of movement occurred between 11:00 and 13:00 $\mathrm{h}$ (mean = $26 \pm 6.1 \mathrm{~m}$; Fig. 2). There was also significantly more activity in spring compared with autumn, winter and summer (BLR, p < 0.01; Table 2). Increased activity during early spring coincided with the breeding season, and 2 of the tagged fish included in diel tracking spawned in early September. Movement of nesting males during diel tracking was negligible, with no movements $>1 \mathrm{~m}$ recorded from the nest site.

There was no significant relationship between diel movement and size (TL) (Table 2). However, when size and time (day, night) were considered together, smaller males were significantly more likely to undertake movements $>10 \mathrm{~m}$ at night than during the day (BLR, $\mathrm{p}=0.04)$. Overall, the distances moved by Maccullochella ikei were significantly greater at night than during the day (MLM, p <0.01). There was also a significant relationship between movement and water depth used by $M$. ikei during the day and night (MLM, p < 0.01). The behaviour was consistent across 6 of the 7 fish monitored, while the remaining fish used the same mean depth $(6.8 \mathrm{~m})$ during both day $( \pm 0.40 \mathrm{~m})$ and night $( \pm 0.38 \mathrm{~m})$. On average, $M$. ikei used water depths of $4.36 \pm 0.145 \mathrm{~m}$ during the day and $3.81 \pm$ $0.145 \mathrm{~m}$ at night.

\section{Habitat selection}

Generally, Maccullochella ikei utilised slow-water habitats, most often in association with cover. Habitat shifts occurred regularly for some individuals, while others changed rarely and often for only short periods before returning to their original site. During high-discharge events $M$. ikei mainly occupied ephemeral backwaters and edge habitats, with inundated riparian vegetation often used as cover. During the breeding season, males continued to use poolrun sections of the river, and all nesting sites $(n=7)$ were located under either large boulders or bedrock shelves.

The river channel was dominated by slow-water habitats: pools $(49 \%)$, glides $(18.3 \%)$ and runs $(7.5 \%)$. Riffles $(12.7 \%)$ and rapids $(12.2 \%)$ were the most abundant of the faster water habitats, while cascades and waterfalls made up $<0.5 \%$. Maccullochella ikei demonstrated a significant preference

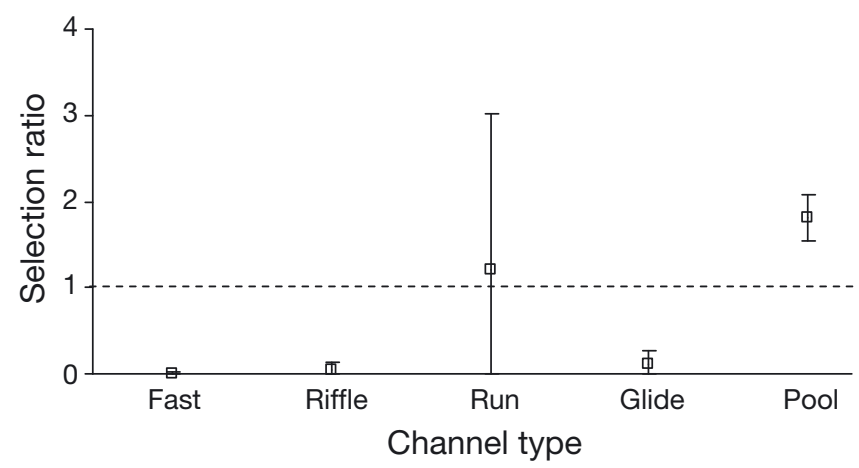

Fig. 3. Maccullochella ikei. Selection ratios and Bonferroniadjusted $95 \%$ confidence intervals of channel type used by M. ikei $(\mathrm{n}=18$; total number of observations $=807)$

for pools (Fig. 3), with $88 \%$ (n = 18, number of observations $=807$ ) of all weekly fixes within pool habitats. Fast water, riffles and glides were rarely used $(<3 \%)$ in comparison to their relative availability $(42 \%)$. There was neither a preference nor avoidance of run habitats (Fig. 3).

Maccullochella ikei used a range of cover types including boulders, woody debris, macrophytes and bedrock shelves. A number of individuals were also located at times in open-water habitats, and these locations were often associated with water depths $>3 \mathrm{~m}$. M. ikei exhibited a significant preference for large boulders (used $=35 \%$; expected $=9 \%$ ) and woody debris (used $=8 \%$; expected $=<1 \%$ ) (Fig. 4). All other cover types were avoided in comparison to their relative availability (Fig. 4).

There were significant differences between the weekly water depths used by Maccullochella ikei (Kruskal-Wallis $H, \mathrm{p}<0.01$ ). The mean depths used by individual fish ranged from $1.7 \pm 0.12$ to $7.6 \pm$ $0.37 \mathrm{~m}$, compared with the mean available depth of $1.9 \pm 0.07 \mathrm{~m}$. There was a significant avoidance by $M$. 


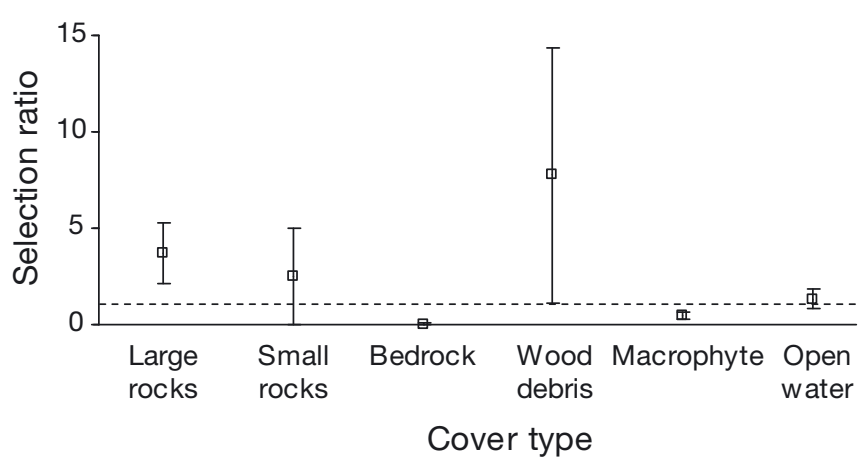

Fig. 4. Maccullochella ikei. Selection ratios and Bonferroniadjusted $95 \%$ confidence intervals of cover type used by $M$. ikei $(\mathrm{n}=18$; total number of observations $=663)$

ikei of waters less than $1 \mathrm{~m}$, but all other depths were used in relative proportion to their availability (Fig. 5). M. ikei were most frequently associated with water depths between 1 and $3 \mathrm{~m}(67 \%)$, while only $10 \%$ of locations were in waters exceeding $5 \mathrm{~m}$. There was no significant relationship between body length and the mean depth of water used $\left(\mathrm{R}^{2}=0.002\right)$.

\section{DISCUSSION}

\section{Movement patterns}

The majority of Maccullochella ikei in the present study returned to the vicinity of their capture site when released, despite the extended period they spent removed from the river, suggesting some degree of homing. The experimental displacement of the Australian native freshwater fishes trout cod Maccullochella macquariensis (Ebner \& Thiem 2009) and golden perch Macquaria ambigua (Crook 2004) resulted in similar behaviour, with both species homing in excess of $2 \mathrm{~km}$ after being relocated. Similarly,

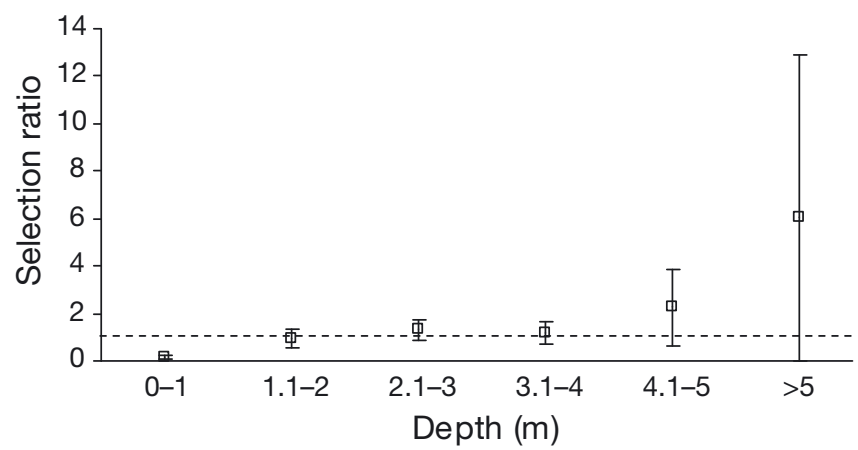

Fig. 5. Maccullochella ikei. Selection ratios and Bonferroniadjusted $95 \%$ confidence intervals of depth categories used by $M$. ikei $(\mathrm{n}=18$; total number of observations $=750$ ) in a separate study involving $M$. macquariensis in the highly regulated Murray River, Koehn et al. (2008) reported that individuals regularly returned to homesites after movements $>1 \mathrm{~km}$. Among Australia's other cod species, the Mary River cod Maccullochella mariensis homed to specific log piles after absences of up to 3 mo (Simpson \& Mapleston 2002), and Murray cod Maccullochella peelii has also been reported to home after taking large-scale, mainly upstream movements of 50 to $130 \mathrm{~km}$ (Koehn et al. 2009, Leigh \& Zampatti 2013).

There was further evidence of post-breeding homing by Maccullochella ikei in the present study. The relatively large-scale breeding and homing movements by $M$. ikei have also been reported for other Australian percichthyids including Maccullochella peelii (Reynolds 1983, Koehn et al. 2009), Macquaria ambigua (Reynolds 1983, O'Connor et al. 2005) and estuary perch Macquaria colonorum (Walsh et al. 2012). All species have been reported to relocate large distances to breed before returning to the vicinity of their original home-site some months later. Post-breeding homing by M. ikei in the present study highlights the need for sufficient river discharge not only to allow movement to spawning sites but also to allow individuals to return to pre-breeding areas after breeding.

The movement patterns of Maccullochella ikei were somewhat predictable but were also often individualistic in nature, as there was no clearly definable period where all individuals behaved the same. However, the majority of individuals did exhibit 2 clear patterns of behaviour at different times during the study: (1) extended periods of restricted movement and strong home-site fidelity, and (2) periods of relatively high mobility, often resulting in large-scale relocations and the establishment of new home sites. The movement patterns of $M$. ikei somewhat reflect the 'restricted movement' model proposed for the behaviour of adult stream fishes (Gerking 1959, Smithson \& Johnston 1999, Rodriguez 2002), but are possibly better described by the 'home range shift' model suggested by Crook (2004) to describe the movements of Macquaria ambigua in the Broken River, Australia. Crook (2004) proposed that movement of Australian adult riverine fish is primarily restricted to core areas or home sites in which the majority of activities occur, and that home-range shifts are facilitated by factors such as external disturbances, competition or movements associated with the species' life history. Recent studies involving 2 of Australia's cod species, Maccullochella macquariensis (Ebner et al. 2007) and Maccullochella peelii 
(Leigh \& Zampatti 2013), have suggested that the behaviour of these species may be more complex than that proposed by Crook (2004), and could include 'return home-range shifts' in the case of $M$. macquariensis, and differing movement types within and between anabranch and main channel habitats in the case of $M$. peelii. However, as with M. ikei in the present study, the overall behaviour of both species in these studies still fits the 'home range shift' model, in that there were extended periods of localised small-scale home-range movements, interspersed with home-range shifts for breeding, dispersal or simple 'exploratory' movements.

The stream length occupied by Maccullochella ikei in the present study is somewhat smaller than that reported for other Australian freshwater cod taxa (e.g. Simpson \& Mapleston 2002, Ebner \& Thiem 2009, Koehn et al. 2009). The differing behaviour is most likely due to the spatially complex nature of the Mann River, where natural barriers such as rapids and waterfalls can frequently restrict the movement of fish. Simpson \& Mapleston (2002) reported that the home range of the closely related Maccullochella mariensis was often restricted by natural log piles or riffles, whilst Ebner et al. (2007) proposed that rapids and riffles may constrain normal ranging behaviour of Macquaria macquariensis in upland rivers in south-eastern Australia. Globally, barriers such as road crossings (Warren \& Pardew 1998, Gibson et al. 2005) and rapids and riffles (Schlosser 1995, Schaefer 2001) have been shown to restrict the home range of stream fishes, resulting in upstream habitats effectively being biologically disconnected for extended periods of time.

The restricted movement and use of refugia by Maccullochella ikei during extreme discharge events has been reported for very few of Australia's largerbodied freshwater fish. Generally, flooding in Australian rivers has been more often associated with large-scale relocations of large-bodied fish (e.g. Reynolds 1983, Koehn et al. 2008, Reinfelds et al. 2013), rather than small lateral movements to refugia, such as $M$. ikei undertook in the present study. However, M. peelii (Koehn 2009), and the congeneric 2-spined blackfish Gadopsis bispinosus (Broadhurst et al. 2011) and river blackfish Gadopsis marmoratus (Koster \& Crook 2008), were reported to use inundated riparian vegetation as cover during high discharge events in a number of rivers in south-eastern Australia. Fish assemblages in smaller, fast-flowing systems commonly resist floods by using submerged riparian vegetation as cover (Matheney \& Rabeni 1995, Franssen et al. 2006) or by making small-scale movements into areas of lower discharge (David \& Closs 2002). It appears that both these strategies are used opportunistically by Australian fish species, including M. ikei in the Mann River, to escape high discharge events.

Increased movement during late winter and spring by male fish in the present study is comparable to the behaviour of other Maccullochella taxa during the same period (Simpson \& Mapleston 2002, Koehn et al. 2008, 2009). Such movement has been hypothesised to be related to breeding, with Australia's other freshwater cod thought to migrate and breed before undertaking a return migration some months later. While there is no clear delineation between the terms migration and movement, generally migration is considered to be a continuous and direct movement from one location to another, and usually from one habitat type to another, such as from freshwater to saltwater (Gerking 1959, Tsukamoto et al. 2009). The behaviour of M. ikei males during the breeding season in the present study was not indicative of migration, as individuals moved sporadically both upstream and downstream before spawning. There was also considerable variation in the distances moved, with one individual moving over $20 \mathrm{~km}$ and not spawning, whilst another moved only $31 \mathrm{~m}$ and spawned. Such behaviour would suggest that movement to breed is not obligatory for M. ikei, but is related more to the proximity of suitable spawning sites and as such cannot be considered a true migration.

\section{Movements in relation to river discharge}

The strong association shown between river discharge and movement of Maccullochella ikei in the present study has underlined the importance of protecting flows at all times of the year to allow the species to disperse. Unregulated river systems such as the Mann naturally have a high level of spatiotemporal heterogeneity (Ward 1989, Richter at al. 1998). During periods of low flow, these types of systems can often become fragmented and as such the capacity of fish wanting to relocate to undertake activities such as feeding or reproduction is temporarily diminished (Schlosser 1995). M. ikei used increases in discharge to move through shallow sections of the river and to move over larger instream barriers such as rapids and waterfalls. Unlike rivers such as those in Australia's heavily regulated MurrayDarling River system, where many of the barriers are anthropogenic and can be remedied with artificial structures such as fish ladders, the majority of barri- 
ers restricting the movement of $M$. ikei in the Mann River are natural and cannot be removed or justifiably bypassed with similar structures. As such, increases in river discharge are the only means by which $M$. ikei can move over larger barriers into adjoining pools.

\section{Diel movement patterns}

The diel movement patterns of Maccullochella ikei were dominated by increased nocturnal activity, with the largest movements occurring around the crepuscular periods of dawn and dusk. Generally, M. ikei used cover or areas of deeper water during the day and more open and shallower areas during the night. Increased nocturnal activity is not uncommon among stream fishes, as many use the cover of darkness to move between home sites or to feed (e.g. Matheney \& Rabeni 1995, Beauchamp \& Van Tassell 2001, Koster \& Crook 2008, Thiem et al. 2008). Increased crepuscular activity is also common among many freshwater fishes (Reebs 2002), including Australian species such as Maccullochella mariensis (Simpson \& Mapleston 2002), Maccullochella macquariensis (Thiem et al. 2008), Gadopsis bispinosus (Broadhurst et al. 2011, Broadhurst et al. 2012) and Australian bass Macquaria novemaculeata (Harris 1985).

The nocturnal behaviour of Maccullochella ikei is consistent with that of an active forager, with individuals during the present study roaming over larger areas, moving into adjoining pools, used shallower habitats and sharing home ranges at night. Similar behaviour has been observed in other foraging freshwater fishes, with most reported to move mainly between dusk and dawn (Matheney \& Rabeni 1995, Beauchamp \& Van Tassell 2001, Broadhurst et al. 2011). The foraging strategy used by $M$. ikei differs somewhat from the original hypothesis that the species is primarily a solitary ambush opportunist, using cover to hide and capture passing prey as it presents (Harris \& Rowland 1996). However, the positioning of some individuals at the base of rapids at night, and the strong association with cover during the day, suggests that ambushing prey may still play a part in the species' overall feeding strategy.

\section{Habitat selection}

The strong selection of instream cover by Maccullochella ikei in the present study is not uncommon among freshwater fish (Pearsons et al. 1992, Talmage et al. 2002, Rosenfeld 2003). Fish in rivers and streams use the concealment provided by instream structure to ambush prey and avoid predators, and as shelter in areas of high stream velocity (Grossman \& Freeman 1987, Savino \& Stein 1989, Cunjak 1996). The selection of boulders by $M$. ikei is, however, somewhat different to that of the other 3 Maccullochella taxa, which have all been reported to exhibit a strong preference for woody debris (e.g. Simpson \& Mapleston 2002, Growns et al. 2004, Nicol et al. 2007, Ebner \& Thiem 2009, Koehn 2009). The difference in habitat selection is most likely a reflection of relative availability, as woody debris is the most abundant cover type in the river systems which the other $3 \mathrm{cod}$ species now principally inhabit (Crook \& Robertson 1999). Whilst M. ikei mainly selected boulders and woody debris, individuals also used macrophytes, bedrock shelves, and deep and open water as cover on a number of occasions. Such habitat selection suggests that the quality and proximity of cover can often be of greater importance than the specific type, as has been suggested for other fish species (Meffe \& Sheldon 1988, Cunjak 1996, Harvey et al. 1999).

Many potamodromous fish species have been shown to travel large distances to spawn (e.g. Pellett et al. 1998, Zigler et al. 2003, Godinho \& Kynard 2006). Whilst it is not the situation in all cases, often these movements involve a shift to different types of habitat. For example, the Connecticut River shortnose sturgeon Acipenser brevirostrum migrates to areas containing distinct rocky substrate (Kynard 2003) to reproduce, while northern pike Esox lucius in the Great Lakes Basin move from the main river channel into flooded wetlands and marshes to breed (Casselman \& Lewis 1996). However, while all breeding males in the present study had moved from their previous week's position, the habitat selected was the same as that used outside of the breeding season. Research into the breeding behaviour of Maccullochella ikei has shown that there is strong intra-specific competition for spawning sites (Butler \& Rowland 2009). The pre-breeding movements of M. ikei may therefore be a case of resident males simply being excluded from their selected site by more aggressive conspecifics, necessitating a shift to the nearest available suitable site.

\section{Management implications}

The behaviour of Maccullochella ikei in relation to river discharge in the present study generally validates previous recommendations made regarding 
the species' flow requirements (Johnson et al. 1987 , New South Wales Fisheries 2000). One of the key suggestions made in the past was that flow regimes should be maintained as near to natural as possible. However, defining the natural flow in most streams and rivers throughout the world is now difficult, as most have been altered or modified to at least some degree (Walker 1985, Kingsford 2000, Roni 2005). Poff et al. (1997) stated that successful river conservation or restoration may fail if the dynamic and individual nature of a flowing water system is not recognised. Any flow management strategy implemented for $M$. ikei should therefore aim to minimise flow stabilisation and incorporate provisions that will allow periodic flooding to facilitate dispersal (McMahon 1986, Poff et al. 1997, McMahon \& Finlayson 2003).

The selection of pools by Maccullochella ikei has highlighted the need to preserve and, where possible, restore deep-water habitats as part of ongoing conservation activities. Many of the coastal streams and rivers of eastern Australia have been subject to significant sedimentation and infilling since European settlement (Ferguson et al. 1999b, Dawson 2002). To date, habitat restoration programs for the species have focused mainly on restoring stream connectivity and revegetating along riparian zones, rather than activities such as pool reclamation (e.g. New South Wales Department of Primary Industries 2006). Whilst a catchment-wide approach is required to ensure the long-term restoration and integrity of pools, in the short-term a more direct approach could potentially be implemented. Such a strategy could include adding physical structures to create pools by damming, and over the longer term via scouring, or the direct creation of pools through the removal of sediment by dredging (Armantrout 1991, Roni et al. 2005).

The information presented in this paper provides direction for the future conservation and management of Maccullochella ikei, but also for the management of other large freshwater fish species. The strong relationship shown between increases in river discharge and increased movement by M. ikei highlights the importance of maintaining or implementing flow regimes that mimic natural flows. River discharge was shown to be particularly important not only during the breeding season, when $M$. ikei moved to locate spawning habitat and to home postbreeding, but also at other times of the year, when they moved between pools to change home sites or to feed. The present study also revealed the role natural barriers play in unregulated river systems in restricting the movements of large-bodied freshwater spe- cies such as M. ikei. Additionally, the strong preference shown for instream cover and for pools further reinforces the need to preserve areas of undisturbed habitat and emphasises that habitat rehabilitation must play an integral part in any future conservation programs for the species. The use of inundated riparian vegetation by $M$. ikei as refugia during high flow events has also added another dimension to the importance of preservation and restoration of riparian zones to ensure the conservation of riverine fishes. In conclusion, the present study has highlighted the need for a holistic approach that encompasses both the terrestrial and aquatic environments when managing large-bodied riverine fish species such as $M$. ikei.

Acknowledgements. The present study is from $\mathrm{PhD}$ research undertaken by G.L.B. and was supported by Southern Cross University, NSW Department of Primary Industries, the Australian Research Council (no. LP0347163) and Rous Water. All sampling was undertaken in accordance with the Australian Code of Practice for the Care and Use of Animals for Scientific Purposes (permit no. 04/12). We thank all the people who gave much of their time to ensure the success of this project, in particular: Robert Predo, Krystal Predo, Ralph Jahrling, Ian Wooden, Jamie Knight, Charlie Mifsud, Jason Hay and Todd Rowland for their help with field work; and Phillip and Melvina Dick, Keith and Carol Mercer, Bob Davies and the local indigenous community for allowing us access to their respective sections of the river. Thanks also to Dr. Bruce Pease, Dr. Brendan Ebner, Dr. Chris Walsh and the anonymous reviewers who commented and helped in the preparation of the final draft.

\section{LITERATURE CITED}

Armantrout NB (1991) Restructuring streams for anadromous salmonoids. In: Colt J, White RJ (eds) Fisheries Bioengineering Symposium: American Fisheries Society Symposium 10. American Fisheries Society, Bethesda, MD, p 136-149.

Armantrout NB (1998) Glossary of aquatic habitat inventory terminology. American Fisheries Society, Bethesda, MD

Arthington AH, Pusey BJ (2003) Flow restoration and protection in Australian rivers. River Res Appl 19:377-395

Beauchamp DA, Van Tassell JJ (2001) Modeling seasonal trophic interactions of adfluvial bull trout in Lake Billy Chinook, Oregon. Trans Am Fish Soc 130:204-216

Broadhurst BT, Dyer JG, Ebner BC, Thiem JD, Pridmore PA (2011) Response of two-spined blackfish Gadopsis bispinosus to short-term flow fluctuations in an upland Australian stream. Hydrobiologia 673:63-77

Broadhurst BT, Lintermans M, Thiem JD, Ebner BC, Wright DW, Clear RC (2012) Spatial ecology and habitat use of the two-spined blackfish Gadopsis bispinosus in an upland reservoir. Aquat Ecol 46:297-309

Butler GL (2001) Age, growth and telemetric tracking of the eastern freshwater cod, Maccullochella ikei (Pisces: Percichthyidae) within the Mann-Nymboida River system, New South Wales. Honours dissertation, Southern Cross 
University, Lismore

Butler GL (2009) Review of the biology and conservation of the endangered eastern freshwater cod Maccullochella ikei, with particular reference to defining environmental water requirements. Unregulated River Water Sharing Plan Ecological Monitoring and Reporting. NSW Department of Water and Energy, Sydney

> Butler GL, Rowland SJ (2008) Using traditional age and growth techniques in endangered species management: eastern freshwater cod Maccullochella ikei. Mar Freshw Res 59:684-693

Butler GL, Rowland SJ (2009) Using underwater cameras to describe the reproductive behaviour of the endangered eastern freshwater cod Maccullochella ikei. Ecol Freshw Fish 18:337-349

Butler GL, Mackay B, Rowland SJ, Pease BC (2009) Retention of intra-peritoneal transmitters and post-operative recovery of four Australian native fish species. Mar Freshw Res 60:361-371

Cadwallader PL (1978) Some causes of decline in range and abundance of native fish in the Murray-Darling River System. Proc R Soc Vic 96:33-43

> Casselman JM, Lewis CA (1996) Habitat requirements of northern pike (Esox lucius). Can J Fish Aquat Sci 53(Suppl 1):161-174

Crook DA (2004) Is the home range concept compatible with the movement of two species of lowland river fish? J Anim Ecol 73:353-366

Crook DA, Robertson AI (1999) Relationship between riverine fish and woody debris; implications for lowland rivers. Mar Freshw Res 50:941-953

Cunjak RA (1996) Winter habitat of selected stream fishes and potential impacts from land-use activity. Can J Fish Aquat Sci 53(Suppl 1):267-282

David BO, Closs GP (2002) Behaviour of stream-dwelling fish before, during, and after high-discharge events. Trans Am Fish Soc 131:762-771

Dawson K (2002) Fish kill events and habitat losses of the Richmond River, NSW Australia: an overview. J Coastal Res 36:216-221.

> Ebner BC, Thiem JD (2009) Monitoring by telemetry reveals differences in movement and survival following hatchery or wild-rearing of an endangered fish. Mar Freshw Res 60:45-57

Ebner BC, Thiem JD, Lintermans M (2007) Fate of 2 yearold, hatchery-reared trout cod Maccullochella macquariensis (Percichthyidae) stocked into two upland rivers. J Fish Biol 71:182-199

Ferguson R, Lampert G, Brierley G (1999a) River Styles ${ }^{\text {TM }}$ in the Mann and Guy Fawkes catchments, North Coast, NSW. Department of Physical Geography, Macquarie University, Sydney

Ferguson R, Lampert G, Brierley G (1999b) River Styles ${ }^{\text {TM }}$ in the Clarence catchment, North Coast, NSW. Department of Physical Geography, Macquarie University, Sydney

> Franssen NR, Gido KB, Guy CS, Tripe JA and others (2006) Effects of floods on fish assemblages in an intermittent prairie stream. Freshw Biol 51:2072-2086

Froese R, Pauly D (eds) (2013) FishBase, version 02/2013. www.fishbase.org

> Gerking SD (1959) The restricted movement of fish populations. Biol Rev 34:221-242

Gibson J, Haedrich RL, Wernerheim CM (2005) Loss of fish habitat as a consequence of inappropriately constructed stream crossings. Fisheries 30:10-17
Godinho L, Kynard B (2006) Migration and spawning of radio-tagged zulega Prochilodus argenteus in a dammed Brazilian river. Trans Am Fish Soc 135:811-824

> Greenberg LA (1991) Habitat use and feeding behavior of thirteen species of benthic stream fishes. Environ Biol Fishes 31:389-401

Grossman LA, Freeman MC (1987) Microhabitat use in a stream assemblage. J Zool 31:389-401

Growns I, Wooden I, Schiller C (2004) Use of instream woody habitat by trout cod Maccullochella macquariensis (Cuvier) in the Murrumbidgee River. Pac Conserv Biol 10:231-265

Harris JH (1985) Diet of Australian bass, Macquaria novemaculeata (Perciformes: Percichthyidae) in the Sydney Basin. Aust J Mar Freshw Res 36:219-235

Harris JH, Rowland SJ (1996) Australian cods and basses. In: McDowall (ed) Freshwater fishes of south-eastern Australia. Reed Books, Sydney, p 150-163

- Harvey BC, Nakamoto RJ, White JL (1999) Influence of large woody debris and bankful flood on movement of adult resident coastal cutthroat trout (Oncorhynchus clarki) during fall and winter. Can J Fish Aquat Sci 56: 2161-2166

Jefferies RL, Rockwell RF, Abraham KF (2004) The embarrassment of riches: agricultural food subsidies, high goose numbers, and the loss of Artic wetlands - a continuing saga. Environ Rev 11:193-232

Johnson HT, Richardson BA, Nemec JF (1987) Flow requirements of the eastern freshwater cod in the Mann River (preliminary study). New South Wales Department of Agriculture, New South Wales Fisheries Research Institute, Cronulla

Kingsford RT (2000) Ecological impacts of dams, water diversions and river management on floodplain wetlands in Australia. Aust Ecol 25:109-127

Koehn JD (2009) Multi-scale habitat selection by Murray cod Maccullochella peelii peelii in lowland rivers. J Fish Biol 75:113-129

Koehn JD, Nicol SJ, McKenzie JA, Lieschke JA, Lyon JP, Pomorin K (2008) Spatial ecology of an endangered native Australian Percichthyid fish, the trout cod Maccullochella macquariensis. Endang Species Res 4: 219-225

Koehn JD, McKenzie JA, O'Mahony DJ, Nicol SJ, O'Connor JP, O'Connor WG (2009) Movements of Murray cod (Maccullochella peelii peelii) in a large Australian lowland river. Ecol Freshw Fish 18:594-602

> Koster W, Crook DA (2008) Diurnal and nocturnal movements of river blackfish (Gadopsis marmoratus) in a south-eastern Australian upland stream. Ecol Freshw Fish 17:146-154

Kynard B (2003) Review of migration, research methods, and passage for downstream migrant fishes in the Northeast USA. In: Lintermans M, Phillips B (eds) Downstream movement of fish in the Murray-Darling Basin. MurrayDarling Basin Commission, Canberra, p 15-23

Kynard B, Zhuan P, Zhang T, Zang L (2003) Ontogenetic behaviour and migration of Darby's sturgeon, Acipenser dabryanus, from the Yangtze River, with notes on body color and development rate. Environ Biol Fishes 66: $27-36$

Leigh SJ, Zampatti BP (2013) Movement and mortality of Murray cod, Maccullochella peelii, during overbank flows in the lower River Murray, Australia. Aust J Zool 61:160-169 
Matheney MP, Rabeni CF (1995) Patterns of movement and habitat use by northern hog suckers in an Ozark stream. Trans Am Fish Soc 124:886-897

McFarlane GA, Wydoski RS, Prince ED (1990) Historical review of the development of external tags and marking. In: Parker NC, Giorgi $\mathrm{AE}$, Heidinger $\mathrm{RC}$, Jester $\mathrm{DB}$, Prince ED, Winans GA (eds) Fish-marking techniques. American Fisheries Society Symposium 7. American Fisheries Society, Bethesda, MD, p 9-29

McMahon TA (1986) Hydrology and management of Australian streams. In: Campbell IC (ed) Stream protection the management of rivers for instream uses. Water Studies Centre, Chisholm Institute of Technology, Melbourne, p 23-44

McMahon TA, Finlayson BL (2003) Droughts and antidroughts: the low flow hydrology of Australian rivers. Freshw Biol 48:1147-1160

Meffe GK, Sheldon AL (1988) The influence of habitat structure on fish assemblage composition in south-eastern blackwater streams. Am Midl Nat 120:225-239

New South Wales Department of Primary Industries (2006) Habitat rehabilitation for the endangered eastern freshwater cod (Maccullochella ikei) in the Richmond River catchment and trout cod (Maccullochella macquariensis) in the Murray catchment, NSW. Report to the New South Wales Environmental Trust. New South Wales Department of Primary Industries, Sydney

New South Wales Fisheries (2000) River flow requirements eastern cod (draft report). Office of Conservation, New South Wales Fisheries, Ballina

New South Wales Fisheries (2004) Eastern freshwater cod (Maccullochella ikei) recovery plan. New South Wales Fisheries, Nelson Bay

> Nicol SJ, Barker RJ, Koehn JD, Burgman MA (2007) Structural habitat selection by the critically endangered trout cod, Maccullochella macquariensis, Cuvier. Biol Conserv 138:30-37

> O'Connor JP, O'Mahoney DJ, O'Mahoney JM (2005) Movements of Macquaria ambigua in the Murray River, southeastern Australia. J Fish Biol 66:392-403

Page E (1944) Clarence River Hydro-electric Gorge Scheme: linking two states to create power production population. Bulletin Newspaper, Sydney

Pearsons TN, Li HW, Lamberti GA (1992) Influence of habitat complexity on resistance to flooding and resilience of stream fish assemblages. Trans Am Fish Soc 121:427-436

Pellett TD, Van Dyck GJ, Adams JV (1998) Season migration and homing of channel catfish in the lower Wisconsin River, Wisconsin. N Am J Fish Manag 18:85-95

Poff NL, Allan JD, Bain MB, Karr JR and others (1997) The natural flow regime: a paradigm for river conservation and restoration. Bioscience 47:769-784

Quinn TP (2005) The behaviour and ecology of Pacific salmon and trout. American Fisheries Society, Bethesda, MS

> Quinn TP, Myers KW (2004) Anadromy and the marine migrations of the Pacific salmon and trout: Rounsefell revisited. Rev Fish Biol Fish 14:421-442

Radinger J, Wolter C (2013) Patterns and predictions of fish dispersal in rivers. Fish Fish, doi: 10.1111/faf.12028

Rankin and Hill Pty Ltd (1981) Possibilities for inland diversion of NSW coastal streams: a review of previous proposals for the diversion of water from NSW coastal streams to the inland. Report to the Water Resources Commission of NSW, Sydney
Rasbash J, Steele F, Browne W, Prosser B (2005) The user's guide to MLwiN. Centre for Multilevel Modelling, University of Bristol, Bristol

Reebs SG (2002) Plasticity of diel and circadian activity rhythms in fishes. Rev Fish Biol Fish 12:349-371

Reinfelds IV, Walsh CT, van der Meulen DE, Growns IO, Gray CA (2013) Magnitude, frequency and duration of instream flows to stimulate and facilitate catadromous fish migrations: Australian bass (Macquaria novemaculeata Perciformes, Percichthyidae). River Res Appl 29: 512-527

- Reynolds LF (1983) Migration patterns of five fish species in the Murray-Darling River system. Aust J Mar Freshw Res 34:857-871

> Richter BA, Baumgartner JV, Braun DP, Powell J (1998) A spatial assessment of hydrologic alteration within a river network. Regul River Res Manag 14:329-340

Rodriguez MA (2002) Restricted movement in stream fish: the paradigm is incomplete, not lost. Ecology 83:1-13

Rogers KB, White GC (2007) Analysis of movement and habitat use from telemetry data. In: Guy CS, Brown ML (eds) Analysis and interpretation of freshwater fisheries data. American Fisheries Society, Bethesda, MD, p 625-676

Roni P (2005) Overview and background. In: Roni P (ed) Monitoring stream and watershed restoration. American Fisheries Society, Bethesda, MD, p 1-12

Roni P, Fayram AH, Miller MA (2005) Monitoring and evaluating instream habitat enhancement. In: Roni P (ed) Monitoring stream and watershed restoration. American Fisheries Society, Bethesda, MD, p 209-236

Rosenberger A, Angermeier PL (2003) Ontogenetic shifts in habitat use by the endangered Roanoke logperch (Percina rex). Freshw Biol 48:1563-1577

Rosenfeld J (2003) Assessing the habitat requirements of stream fishes: an overview and evaluation of different approaches. Trans Am Fish Soc 132:953-968

Rowland SJ (1983) Spawning of the Australian freshwater fish Murray cod, Maccullochella peeli (Mitchell), in earthen ponds. J Fish Biol 23:525-534

Rowland SJ (1993) Maccullochella ikei, an endangered species of freshwater cod (Pisces: Percichthyidae) from the Clarence River system, NSW and $M$. peelii mariensis, a new subspecies from the Mary River system, QLD. Rec Aust Mus 45:121-145

Rowland SJ (2013) Hatchery production for conservation and stock enhancement: the case of Australian freshwater fish. In: Allan G, Burnell G (eds) Advances in aquaculture technology. Woodhead Publishing, Cambridge, p 558-595

Savino JF, Stein RA (1989) Behavior of fish predators and their prey: habitat choice between open water and dense vegetation. Environ Biol Fishes 24:287-293

Schaefer J (2001) Riffles as barriers to interpool movement by three cyprinids (Notropis boops, Campostoma anomalum and Cyprinella venusta). Freshw Biol 46:379-388

Schlosser IJ (1995) Critical landscape attributes that influence fish population dynamics in headwater streams. Hydrobiologia 303:71-81

- Selosse PM, Rowland SJ (1990) Use of common salt to treat ichthyophthiriasis in Australian warm water fishes. Prog Fish-Cult 52:124-127

Simonson TD, Lyons J, Kanehl PD (1994) Guidelines for evaluating fish habitat in Wisconsin streams. US Forest Services General Technical Report NC-164, St Paul, MN 
Simpson RR, Mapleston AJ (2002) Movements and habitat use of the endangered Australian freshwater Mary River cod, Maccullochella peelii mariensis. Environ Biol Fishes 65:401-410

Smithson EB, Johnston CE (1999) Movement patterns of stream fishes in a Ouachita Highlands stream: an examination of the restricted movement paradigm. Trans Am Fish Soc 128:847-853

Snowy Mountains Engineering Corporation (2007) Integrated water supply options for north east New South Wales and south east Queensland. Report prepared by Snowy Mountains Engineering Corporation for the National Water Commission. Snowy Mountains Engineering Corporation, Melbourne

Talmage PJ, Perry JA, Goldstein RM (2002) Relation of instream habitat and physical conditions to fish communities of agricultural streams in the Northern Midwest. N Am J Fish Manag 22:825-833

Taylor MK, Cooke SJ (2012) Meta-analyses of the effects of river flow on fish movement and activity. Environ Rev 20: 211-219

Thiem JD, Ebner BC, Broadhurst BT (2008) Diel activity of the endangered trout cod (Maccullochella macquariensis) in the Murrumbidgee River. Proc Linn Soc NSW 129: 167-173

Thirgood S, Mosser A, Tham S, Hopcraft G and others (2004) Can parks protect migratory ungulates? The case of the Serengeti wildebeest. Zool Soc Lond 7:113-120

Editorial responsibility: Eric Gilman,

Honululu, Hawaii, USA
Tsukamoto K, Miller MJ, Kotake A, Aoyama J, Uchida K (2009) The origins of fish migration: the random escapement hypothesis. In: Haro AJ, Smith KL, Rulifson CM, Moffitt RJ and others (eds) Challenges for diadromous fishes in a dynamic global environment. American Fisheries Society, Bethesda, MD, p 45-62

Walker KF (1985) A review of the ecological effects of river regulation in Australia. Hydrobiologia 125:111-129

Walsh CT, Reinfelds IV, Gray CA, West RJ, van der Meulen DE, Craig JR (2012) Seasonal residency and movement patterns of two co-occurring catadromous percichthyids within a south-eastern Australian river. Ecol Freshw Fish 21:145-159

Ward JV (1989) The four dimensional nature of lotic ecosystems. J N Am Benthol Soc 8:2-8

Warren ML, Pardew MG (1998) Road crossings as barriers to small-stream fish movement. Trans Am Fish Soc 127: 637-644

Whitfield AK, Panfili J, Durand JD (2012) A global review of the cosmopolitan flathead mullet Mugil cephalus Linnaeus 1758 (Teleostei: Mugilidae), with emphasis on the biology, genetics, ecology and fisheries aspects of the apparent species complex. Rev Fish Biol Fish 22: 641-681

> Zigler SJ, Dewey MR, Knights BC, Runstrom AL, Steingraeber MT (2003) Movement and habitat use by radiotagged paddlefish in the upper Mississippi River and tributaries. N Am J Fish Manag 23:189-205

Submitted: March 5, 2013; Accepted: October 16, 2013 Proofs received from author(s): January 14, 2014 